\title{
The effect of calcium phosphate nanoparticles on hormone production and apoptosis in human granulosa cells
}

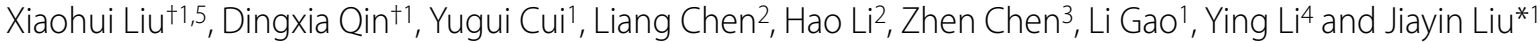

\begin{abstract}
Objectives: Although many nanomaterials are being used in academia, industry and daily life, there is little understanding about the effects of nanoparticles on the reproductive health of vertebral animals, including human beings. An experimental study was therefore performed here to explore the effect of calcium phosphate nanoparticles on both steroid hormone production and apoptosis in human ovarian granulosa cells.

Methods: Calcium phosphate nanoparticles uptaking was evaluated by transmission electron microscopy (TEM). The cell cycle was assessed with propidium iodide-stained cells (distribution of cells in G0/G1, S, and G2/M phases) by flow cytometry. The pattern of cell death (necrosis and apoptosis) was analyzed by flow cytometry with annexin V-FITC/PI staining. The expression of mRNAs encoding P450scc, P450arom and StAR were determined by RT-PCR. Progesterone and estradiol levels were measured by radioimmunoassay.

Results: TEM results confirmed that calcium phosphate nanoparticles could enter into granulosa cells, and distributed in the membranate compartments, including lysosome and mitochondria and intracellular vesicles. The increased percentage of cells in $\mathrm{S}$ phase when cultured with nanoparticles indicated that there was an arrest at the checkpoint from phase S-to-G2/M (from $6.28+/-1.55 \%$ to $11.18+/-1.73 \%, \mathrm{p}<0.05$ ). The increased ratio of $\mathrm{S} /(\mathrm{G} 2 / \mathrm{M}$ ) implied the inhibition of DNA synthesis and/or impairment in the transition of the $S$ progression stage. The apoptosis rate of normal granulosa cells was $7.83+/-2.67 \%$, the apoptotic rate increased to $16.53+/-5.56 \%(P<0.05)$ after the cells were treated with 100 microM calcium phosphate nanoparticles for 48 hours. Treatment with calcium phosphate nanoparticles at concentrations of 10-100 microM didn't significantly change either the progesterone or estradiol levels in culture fluid, and the expression levels of mRNAs encoding P450scc, P450arom and StAR after $48 \mathrm{~h}$ and $72 \mathrm{~h}$ period of treatment.

Conclusion: Calcium phosphate nanoparticles interfered with cell cycle of cultured human ovarian granulosa cells thus increasing cell apoptosis. This pilot study suggested that effects of nanoparticles on ovarian function should be extensively investigated.
\end{abstract}

\section{Background}

Nanoparticles possess nanostructure-dependent properties due to their small size, chemical composition, surface charge, solubility and/or shape [1]. Despite the wide applications of nanomaterials, there is a serious lack of information concerning the impact of manufactured

*Correspondence: jyliu_nj@126.com

${ }^{1}$ Center of Clinical Reproductive Medicine, First Affiliated Hospital, Jiangsu Key Laboratory of Reproductive Medicine, Nanjing Medical University, Nanjing 210029, China

+ Contributed equally

Full list of author information is available at the end of the article nanomaterials on human health and the environment. Typically, the nanoparticles are small enough to penetrate through very small capillaries into the human tissues and cells. Because nanoparticles can pass through biological membranes, they can affect the physiology of most cells, including brain and testes [2-4]. Application of nanomaterials leads to considerable concern regarding its potential biological effects and toxicity in humans $[5,6]$. The major toxicological concern is that some of the manufactured nanomaterials are redox active $[7,8]$, and some particles transport across cell membranes, especially into the 
mitochondria [9]. The reported findings were controversial.

Hydroxyapatite (HA, a kind of calcium phosphate) nanoparticles are similar to human bone in chemical composition and have long been appreciated for their biocompatibility. HA is now one of the most widely used materials in the bone-repairing field. Calcium phosphate is the primary mineral phase of human and animal bone and tooth. Such a mineral phase, with its plate-like or needle-like shape, typically varies in size from a very few to hundreds of nanometers. HA nanomaterial has also been studied for various applications, including orthopedics, dentistry, and food science, with many research topics involving the mineral's interaction with cells [10].

Reproduction is a complex biological process that is particularly sensitive to environmental endocrine disruptors. Many chemicals have negative impacts on gametogenesis and hormone reproduction by either directly affecting germ cells and indirectly affecting on somatic nursing cells [11]. Ovarian granulosa cells play a major role in maintaining ovarian function, health, and female fertility. Cadmium oxide at lower concentrations promoted apoptosis rather than necrosis in the mammalian germline stem cells, thus leaving the plasma membrane intact [12]. Some intracellular organelles involved in steroidogenesis were infiltrated and/or altered due to the presence of the nanogold particles [11]. Calcium phosphate nanoparticles have been used clinically so that we will study carefully their effect on the female reproductive system and reproductive health in the future work.

The hypothesis has been made that HA nanopaticles themselves and many regulatory agents delivered by this kind of nanopaticles could have some effects on steroidgenesis and follicular development and maturation in vivo and in vitro. In this pilot paper, we firstly investigated the effect of calcium phosphate nanoparticles itself on hormone production and apoptosis in human granulosa cells cultured in vitro.

\section{Methods}

\section{Chemicals}

A solution with a $\mathrm{Ca} / \mathrm{P}$ ratio of 1.67 was prepared with 60 $\mathrm{mM}$ of $\mathrm{Ca}\left(\mathrm{NO}_{3}\right)_{2} \cdot 4 \mathrm{H}_{2} \mathrm{O}$ and $36 \mathrm{mM}$ of $\mathrm{NaH}_{2} \mathrm{PO}_{4} \cdot 2 \mathrm{H}_{2} \mathrm{O}$ $[10,13,14]$. The solution was stirred vigorously and heated to $85^{\circ} \mathrm{C}$ and then the same volume of concentrated ammonium hydroxide solution $\left(28-30 \% \quad \mathrm{NH}_{3}\right)$ was quickly added to the solution, which immediately induced nanoparticle precipitation. The mixture was held at $85^{\circ} \mathrm{C}$ for approximately 24 hours to ensure a complete conversion of the starting material to HA. After fabrication, the mixture was then cooled to room temperature and the liquid part was then diluted until the $\mathrm{pH}$ dropped below 9 without any HA nanoparticles being lost. The rod-like crystal was used in this study (Fig 1). The somall-

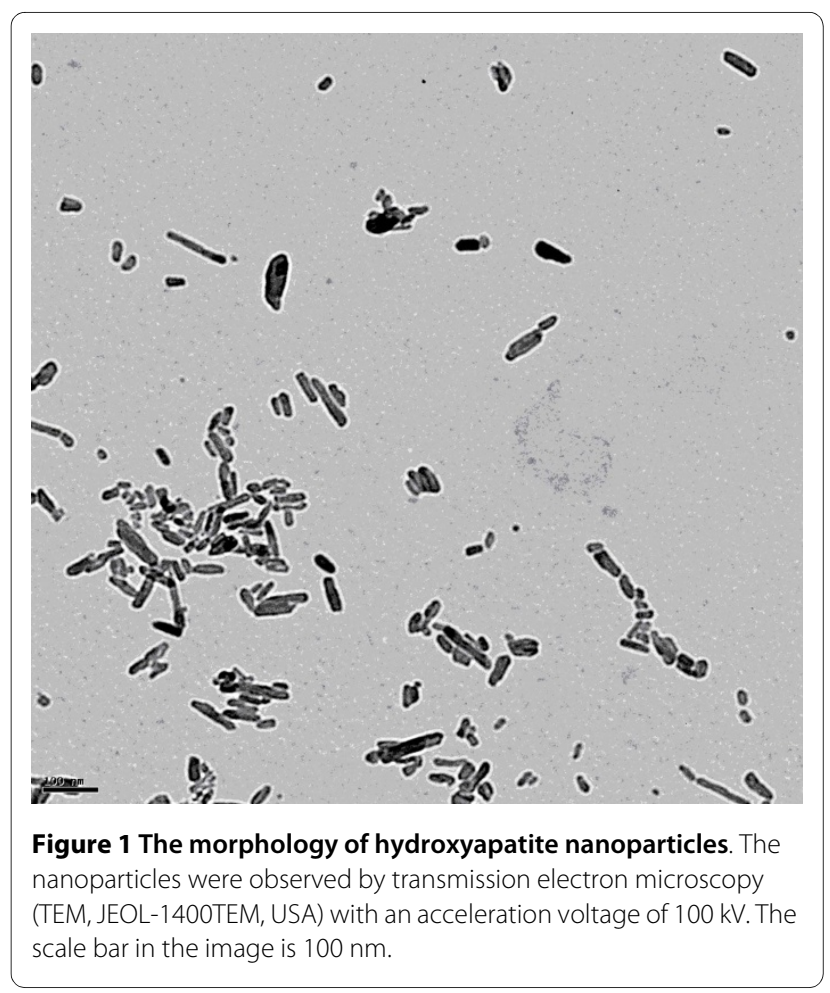

est was $20-30 \mathrm{~nm}$, and particles less $10 \%$ were greater than $100 \mathrm{~nm}$. Dry particle of HA prepared is stable in room temperature.

4-androstene-3,17-dione, Percoll and fetal bovine serum (FBS) were purchased from Sigma-Aldrich (St. Louis, MO). Collagenase Type I was obtained from Worthington Biochemical Corp. (Lakewood, NJ). Antibioticantimycotic preparation (penicillin, 10,000 IU/mL; streptomycin, $10,000 \mathrm{mg} / \mathrm{mL}$; amphotericin $\mathrm{B}, 25 \mathrm{mg} / \mathrm{mL}$ ) were purchased from Grand Island Biological Co. (Grand Island, NY). HEPES was purchased from American Bioanalytical (Natick, MA).

\section{Cell culture}

\section{Isolation of granulosa cells}

Granulosa cells for in vitro experimentation were collected from infertilite women who undergoing IVF-ET treatment $[11,15]$. The women's follicles were punctured with a hypodermic needle to extrude granulosa cells into dish, then, centrifuged $(200 \times g, 5 \mathrm{~min})$ and resuspended in DMEM/F12 containing antibiotics and 10\% FBS. The blood cells were separated by $50 \%$ Percoll and centrifuged at $600 \times g$ for $5 \mathrm{~min}$. Written consent was provided by all patients. The research project was approved by the Human Research Ethics Committee of First Affiliated Hospital, Nanjing Medical University.

\section{Cell culture}

Every time, we can get samples from 8-10 patients. Those cells, after separated by Percoll, were pooled together, in 
which the inter-individual variability should be eliminated or be a low level. Cells were then cultured in DMEM/F12 supplemented with l-glutamine (2 mL), 10\% FBS, penicillin $(10,000 \mathrm{IU} / \mathrm{mL})$, streptomycin $(10,000 \mathrm{mg} /$ $\mathrm{mL})$ and amphotericin $\mathrm{B}(25 \mathrm{mg} / \mathrm{mL})$ at $37^{\circ} \mathrm{C}$ in an atmosphere of $5 \% \mathrm{CO}_{2}$. Cultures were carried out in 6-well plates (Corning Glass Works, Corning, NY) and 12-well plates. The cultured cells in the 12-well plates were used for hormone analysis and those in the 6-well plates were used for isolation of mRNAs and cell cycle analysis.

\section{HA nanoparticles treatment}

After an initial $72 \mathrm{~h}$ of culture in DMEM/F12 medium with $10 \%$ FBS, the culture medium was carefully removed and replaced with fresh medium. Next, the granulosa cells were simultaneously exposed to different concentrations of calcium phosphate nanoparticles. In addition, 4androstene-3,17-dione (final concentration, $500 \mathrm{nM}$ ) was added into the granulosa cell medium as a substrate for estrogen biosynthesis. Ethanol was added to the negative control cells to exclude the effect of the dissolvent. All experiments were duplicated 3 or 4 times. The experiment of every batch was grouped as follows. Group I was treated with only 4-androstene-3,17-dione as control; Group II was treated with HA nanoparticles $(10 \mu \mathrm{M})$ and 4-androstene-3, 17-dione; Group III was treated with HA nanoparticles $(100 \mu \mathrm{M})$ and 4-androstene-3,17-dione. The culture medium in the 12-well plates was collected after $48 \mathrm{~h}$ and stored at $-80^{\circ} \mathrm{C}$ for hormone analysis. Cells cultured in the 6-well plates were lysed with TRIzol and stored at $-80^{\circ} \mathrm{C}$ for mRNAs analysis. For each experiment each assay was performed in triplicate. Cells cultured in the 6-well plates were also fixed in $80 \%$ ethanol for cell cycle analysis.

\section{Cell preparation for TEM}

Granulosa cells were exposed during $2 \mathrm{~h}, 4 \mathrm{~h}, 24 \mathrm{~h}, 48 \mathrm{~h}$ and $72 \mathrm{~h}$ to nanoparticles $(100 \mu \mathrm{M})$. They were fixed with $2.5 \%$ glutaraldehyde, post-fixed with $\mathrm{OsO}_{4}$ and dehydrated in graded concentrations of ethanol [8,9] then embedded in Epon. Ultra-thin sections were cut $(80 \mathrm{~nm})$, counterstained with lead citrate and uranyl acetate then observed with a Philips CM 12 electron microscope at 80 $\mathrm{kV}$.

\section{Cell cycle analysis}

$5 \times 10^{5}$ granulosa cells were plated in 6-well plates and incubated in DMEM/F12 with $0.5 \%$ FBS for 48 h to synchronize the cells in G0/G1 phase by serum deprivation $[16,17]$. Cells were then induced to re-enter the cell cycle by incubation in fresh medium with the calcium phosphate nanoparticles at the final concentration (determined from the growth assay results) for a further $48 \mathrm{~h}$.
The cellular DNA content was determined by flow cytometry, as described previously. We collected the floating and attached cells using pancreatic enzyme and resuspended them in DMEM/F12. The cells were fixed for $30 \mathrm{~min}$ in an ice-cold $80 \%$ ethanol solution containing ribonuclease (RNase, $2 \mathrm{mg} / \mathrm{ml}$ ). We washed the cells in $\mathrm{PBS}$, and then stained them with propidium iodide (PI) for $10 \mathrm{~min}$. The PI-elicited fluorescence was measured for individual cells using a flow cytometer (FACSCalibur, Becton, Dickinson \& Co., Tokyo, Japan) with laser excitation at $488 \mathrm{~nm}$. Emissions greater than $590 \mathrm{~nm}$ were collected in a linear/log scale fashion. We analyzed a total of $1 \times 10^{6}$ cells for each sample and determined the percentages of cells in G0/G1, S, and G2/M phases using standard ModiFIT and CELLQUEST software (Becton, Dickinson \& Co.).

\section{Radioimmunoassay}

The concentrations of progesterone and estradiol in medium were assessed using commercially available radioimmunoassay kits (Bei Fang Biotechnology Corp., Beijing, China) according to the manufacturer's protocol. The intra-assay and inter-assay variations of the kits were both less than $10 \%$.

\section{Semi-quantitative RT-PCR}

After the supernatants were collected for steroid hormone analysis, the cells in the corresponding wells were harvested for mRNA extraction using Trizol reagent according to the manufacturer's protocol. Extracted RNA was treated with DNase prior to measuring RNA content by spectrometry at OD260/280. Equal amounts of RNA (500 ng) were reverse-transcribed into cDNA as previously described [18], using the following thermocycler protocol: $70^{\circ} \mathrm{C}$ for $5 \mathrm{~min}$ and $42^{\circ} \mathrm{C}$ for $90 \mathrm{~min}$.

The expression of P450scc, P450arom and StAR mRNAs in the granulosa cells were measured by the semi-quantitative RT-PCR. The primer pairs are shown as follows: 1) P450scc: F: 5'-GTGACAATGGCTGGCTAA-3', R: 3'-GAGGAATCGTTCTGGGTT-5', 2) P450arom: F: 5'-CACCTCTAACACGCTCTT-3', R: 3'AATCAACTCAGTGG CAAA-5, 3) StAR: F: 5'AGGAAGGACGAAGAACCA-3', R: 3'-CAGCCGAG AACCGAGTAG-5'. PCR was performed in a total volume of $20 \mu \mathrm{l}$. $\beta$-Actin mRNA abundance served as an internal control [18-21].

\section{Statistical analysis}

Data were expressed as mean \pm SD from at least three independent experiments. Statistical analysis was performed using one-way analysis of variance (ANOVA) and $t$ test. Values were determined to be significant when $P<$ 0.05 . 


\section{Results}

\section{Effect of HA nanoparticles on granulosa cells}

TEM examination was performed on granulosa cells post $2 \mathrm{~h}, 4 \mathrm{~h}, 24 \mathrm{~h}, 48 \mathrm{~h}$ and $72 \mathrm{~h}$ exposure to HA nanoparticles. HA nanoparticles were observed in granulosa cells (Fig. 2). Further analysis indicated that HA nanoparticles were localized in the cytoplasm, mostly in membranate compartments, including lysosome and mitochondria, thecal organelles (Fig 2, arrow), besides particles existing out of cells, surrounding cells. Compared with control cells, no visible morphological changes were detected in cells exposed to HA nanoparticles.

\section{Flow cytometric analysis of cell cycle distribution and apoptosis}

The cell cycle distribution was analyzed by MultiCycle software to investigate the effect of calcium phosphate nanoparticles on the cell cycle, as shown in Fig 3. Granulosa cells were treated with 10 and $100 \mu \mathrm{M}$ concentrations of calcium phosphate nanoparticles for $48 \mathrm{~h}$. An accumulation of cells in the $\mathrm{S}$ phases (from $6.28 \pm 1.55 \%$ to $11.18 \pm 1.73 \%$ ) was observed. Compared with control, percentage of cells in G2/M phase in Group III increased

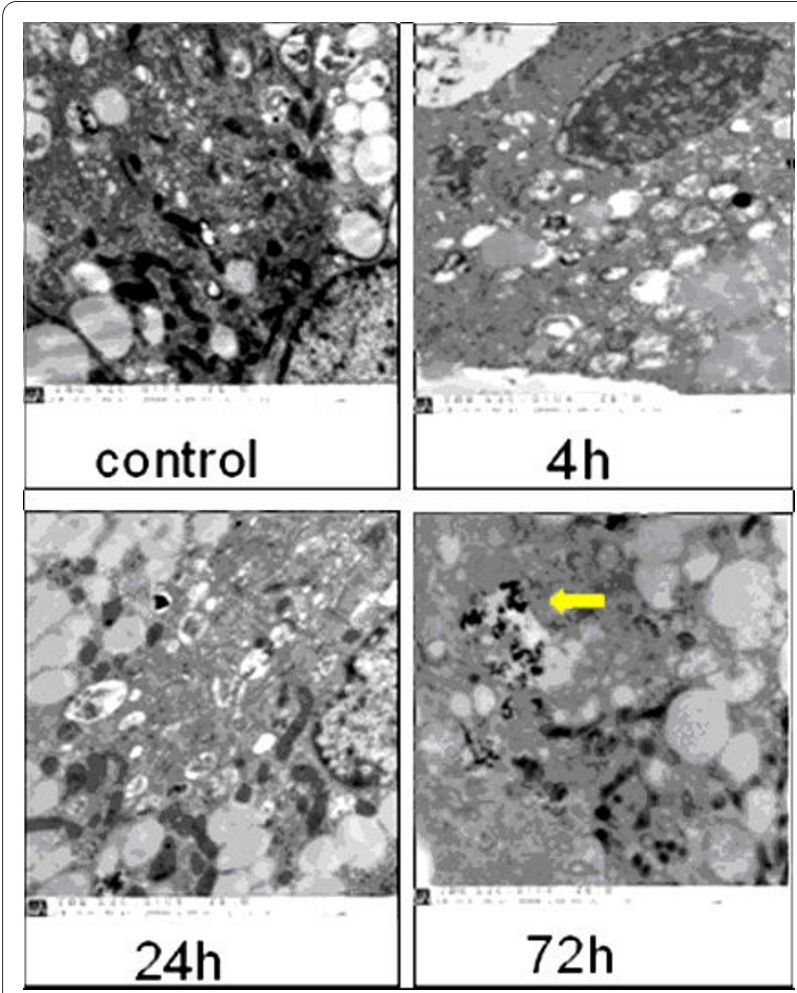

Figure 2 TEM observation of granulosa cells exposed to calcium phosphate nanoparticles. Cells were exposed during $72 \mathrm{~h}$ to $100 \mu \mathrm{M}$ of nanoparticles. Nanoparticles were internalized in cells and localized in cytoplasms, mostly in membranate compartments, including lysosome and mitochondria, thecal organelles (arrow). The scale bar in the image is $500 \mathrm{~nm}$. significantly ( $<0.05$ ) (Fig. 3A). The apoptosis rate of control group was $7.83 \pm 2.67 \%$, but the apoptotic population significantly increased to $16.53 \pm 5.56 \%$ after $48 \mathrm{~h}$ treatment with $100 \mathrm{uM}$ calcium phosphate nanoparticles $(\mathrm{P}<0.05)$ (Fig 4A). At the same time, the proportion of the cells in $\mathrm{S} /(\mathrm{G} 2 / \mathrm{M})$ phase increased perceptibly $(0.89 \pm$ $0.11 \%$ to $1.38 \pm 0.32 \%)(\mathrm{P}<0.05)$. The increased percentage of cells in the $S$ phase when treated with HA nanoparticles indicated that there was an arrest at the checkpoint from phase S-to-G2/M, while an increase in the S/(G2/ $\mathrm{M})$ ratio implied inhibition of DNA synthesis and/or impairment in the transition or the $S$ progression stage (Fig. 3B).

\section{Production of progesterone and estradiol and expression of mRNAs encoding P450scc, P450arom and StAR in granulosa cells after treatment with HA nanoparticles}

As shown in Fig 4, treatment with calcium phosphate nanoparticles at concentrations of $10 \mu \mathrm{M}$ and $100 \mu \mathrm{M}(48$ $\mathrm{h}, 72 \mathrm{~h}$ ) did not cause significant change in either progesterone and estradiol levels (Fig. $4 \mathrm{~A}, P>0.05$ ), and in expression of mRNAs encoding P450scc, P450arom and StAR (Fig 4B, C). By semi-quantitative RT-PCR, we performed a comparative analysis of gene expression in cultured cells exposed to HA nanoparticles and those not exposed $(P>0.05)$.

\section{Discussion}

Despite the potential benefits of nanotechnology, some studies have indicated that certain nanoparticles might cause adverse effects because of their small size and unique properties [22]. For example, HA is now one of the most widely used materials in the bone-repairing field or used as medical adjuvant. Nanomaterials can enter human tissues through several ports via the lungs after inhalation [23], through the digestive system [24], and possibly through the skin [25]. It has been confirmed that nanoparticles could distributed and/or accumulated in reproductive system, ovary and testis $[2,3,22]$. Due to their small size, chemical composition, surface charge, solubility and/or shape, nanoparticles could affect hormone production and fertility, and reproductive health.

TEM observation suggested that calcium phosphate nanoparticles entered into the cultured human granulosa cells and located in thecal organelles within cytoplasm, including lysosome and mitochondria besides particles existing out of cells, surrounding cells (Fig 2). By our protocol prepared HA nanoparticles, two kinds of hydroxyapatite with different nanocrystal morphology were obtained via a simple aqueous precipitation method under different reactants molar ratios. Under $\mathrm{Ca} / \mathrm{P}$ molar ratio of $1.67 / 1$, rod-like crystal was produced, while under $\mathrm{Ca} / \mathrm{P}$ molar ratio of $1.80 / 1$, spherical crystal was produced $[13,14,21]$. The rod-like crystal was used in this 

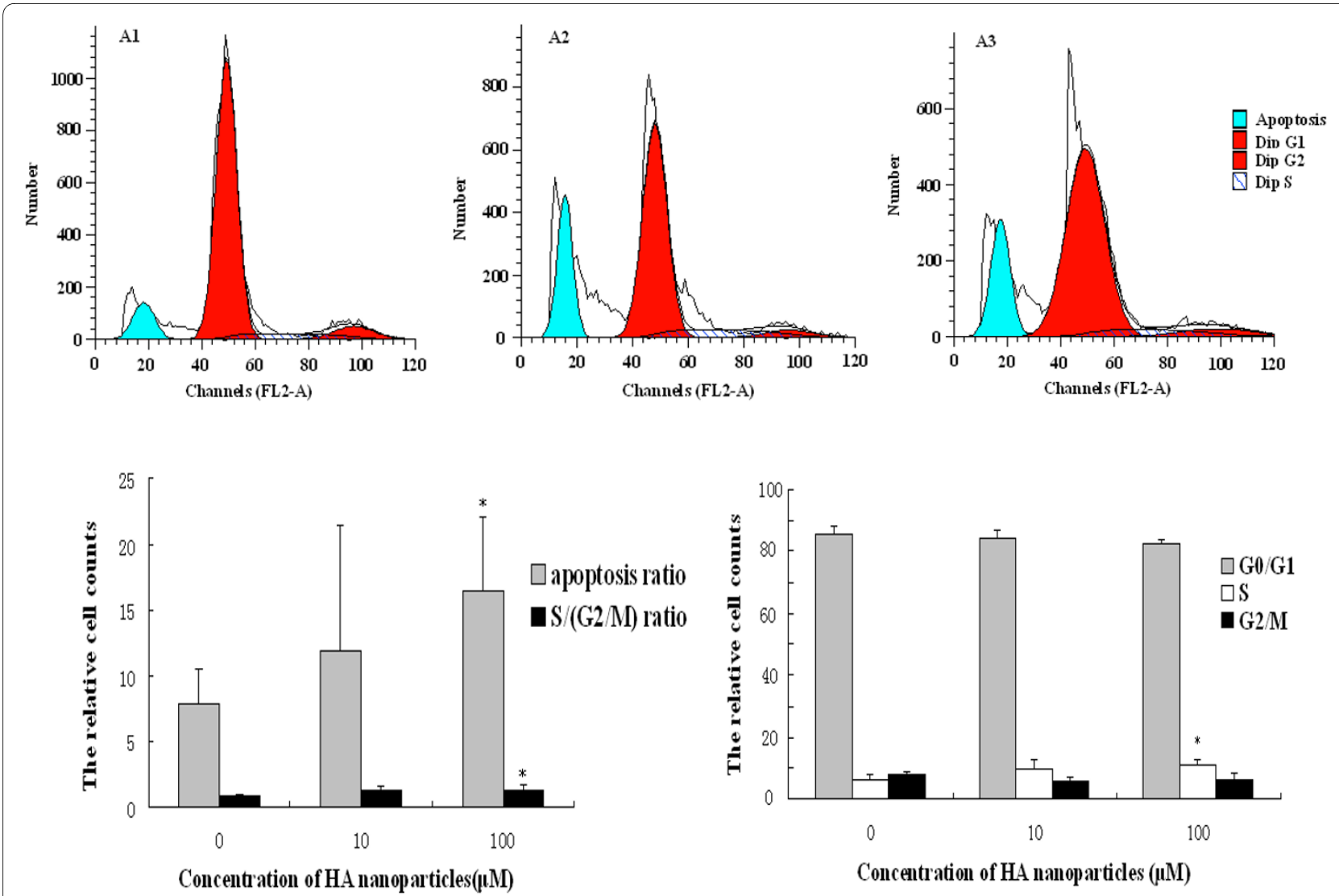

Figure 3 Apoptotic population and flow cytometric analysis of granulosa cell cycle distribution. (A) Flow cytometric analysis of calcium phosphate nanoparticles induced apoptosis in granulosa cells using annexin V-FITC/PI. The x-axis represents fluorescent intensity on a logarithmic scale, whereas the $y$-axis represents the number of events: (A1) Control; (A2) Treatment with $10 \mu$ M calcium phosphate nanoparticles; (A3) Treatment with $100 \mathrm{\mu M}$ calcium phosphate nanoparticles; the green peak refers to the apoptotic population. (B C) The results were analyzed by Mod Fit LT 3.0; Data were presented as mean $\pm S D(n=3) .{ }^{*} p<0.05$, compared with the control group $(0 \mu M)$.

study (Fig 1). Dry HA particle prepared is stable in room temperature, we usually stored at $4^{\circ} \mathrm{C}$ in the refrigerator for longer time over months. The suspended particles were not stable within medium and within cell. Small particles could polymerizat while large particles could schizolysis, totally, calcium phosphate nanoparticles in medium trended to aggregation. So, the suspension of HA nanoparticles in medium was freshly prepared once before the beginning of the each experiment. Based on others' modeling work, nanoparticles in 20-30 nm are easier to penetrate cell walls and larger size make this more difficult $[11,26,27]$. We found that HA nanoparticles distributed in membranate compartments within cells (Fig 2). It was also shown by others $[13,14,21,28]$. There are two kinds of endocytosis, phagocytosis and pinocytosis [29,30] Phagocytosis is restricted to specialized cells such as macrophages, monocytes and neutrophils. Pinocytosis included macropinocytosis (for particles $>1 \mu \mathrm{m})$, clathrin-mediated endocytosis $(\sim 120$ $\mathrm{nm})$, caveolin-mediated endocytosis $(\sim 60 \mathrm{~nm})$ or clathrin- and caveolin-independent endocytosis $(\sim 90 \mathrm{~nm})$.
Due to their size, HA nanoparticles agglomerates were more likely to enter into cells through enter into cells through composite endocytosis.

After treatment with different concentrations of calcium phosphate nanoparticles for $48 \mathrm{~h}$, an accumulation of cells in the $S, S /(G 2 / M)$ and apoptotic population phases was observed (Fig 3). The cell cycle is a complex process by which cells receive different growth controlling signals that are integrated and processed at various points known as checkpoints [31]. The cell growth is controlled when cells are not allowed to proceed further than these checkpoints. Our data suggested that inhibition of cell growth by HA nanoparticles mainly elicit change in proliferation dynamics, the redistribution of cells along the cell cycle. The increased apoptosis rate was linked to cell cycle arrest. Cadmium oxide nanoparticles at lower concentrations promoted apoptosis rather than necrosis in the mammalian germline stem cells. Mitochondria play a central role in the regulation of apoptotic signaling [32-34]. Potential disord of mitochondria is one of the earliest intracellular events that occur following induc- 
A

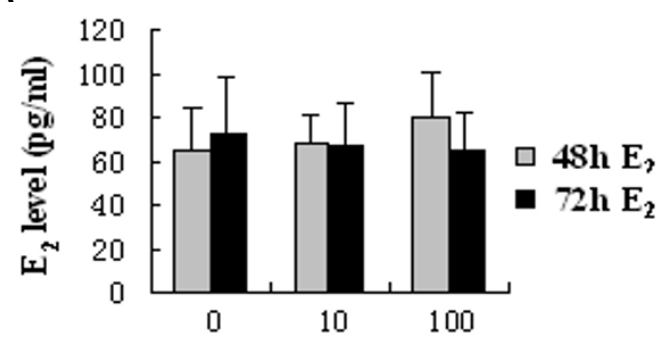

Concentration of $\mathrm{HA}$ manoparticles (uM)

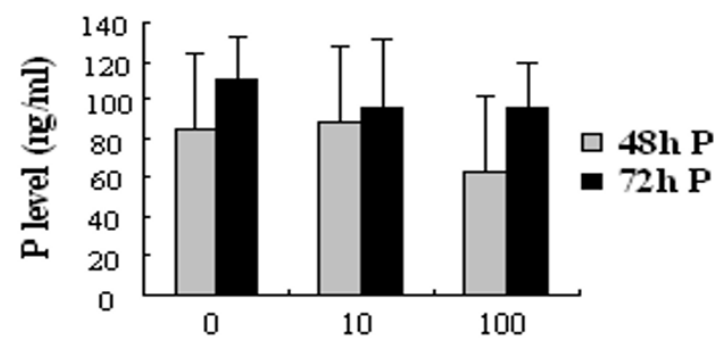

Concentration of HA nanoparticles (uM)
B

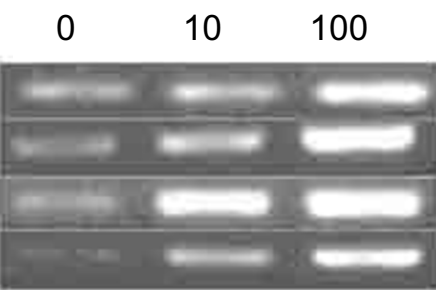

C actin

P450scc

P450arom

StAR

\section{$\begin{array}{lll}0 & 10 & 100\end{array}$}

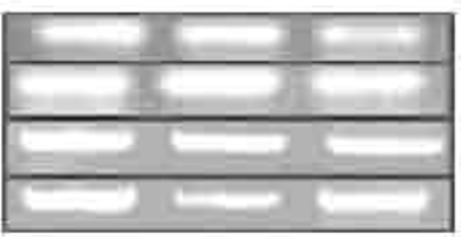

$72 \mathrm{~h}$
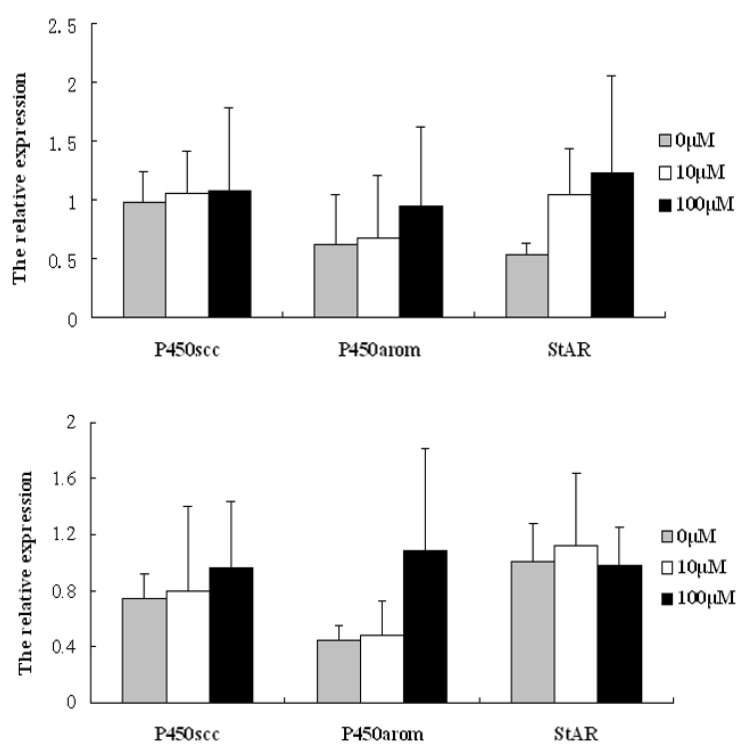

Figure 4 Effect of calcium phosphate nanoparticles on P450scc, P450arom and StAR mRNA expression in human granulosa cells in vitro. Granulosa cells were cultured as described in the text. Following the measurement of steroid hormone levels (A). RT- PCR was used to determine the expression of P450scc, P450arom and StAR mRNAs in the cultured granulosa cells after $48 \mathrm{~h}$ (B) and $72 \mathrm{~h}$ (C) with calcium phosphate nanoparticles. Experiments were repeated three times during separate times and Agarose gel electrophoresis of the PCR products.

tion of apoptosis [35]. Thus, calcium phosphate nanoparticles could induce increase of cells arrest in $\mathrm{S}, \mathrm{S} /(\mathrm{G} 2 / \mathrm{M})$ and increased apoptotic population by interferencing mitochondrial structure and function [32,34] Intracellular free calcium level could also be increased by HA treatment. Pezzatini $\mathrm{S}$ et al used HA concentrations ranging from 2 to $10 \mu \mathrm{g} / \mathrm{ml}$ to study microvascular endothelial cell [21]. Qiang Fu et al tried HA with 31.25 to $250 \mu \mathrm{g} / \mathrm{ml}$ in Osteosarcoma U2-OS cell [14]. In our study, granulosa cells were treated with HA nanoparticles at two concentrations of 10 and $100 \mu \mathrm{M}$, equally 5 and $50 \mu \mathrm{g} / \mathrm{ml}$. HA particles was suspensed in DMEM/F12 medium, $\mathrm{pH}$ did not changed significantly. So, cell apoptosis was unlikely resulted from the elevated alkaline by HA nanoparticles in culture medium.

We evaluated steroid hormone production and mRNAs expression encoding P450scc, P450arom and StAR in granulosa cells exposed to HA nanoparticles for $48 \mathrm{~h}$ and
$72 \mathrm{~h}$ (Fig 4). HA nanoparticles at 10 and $100 \mu \mathrm{M}$ did not significantly change progesterone and estradiol production. Even though these results did not show the functional disord as well as its molecular mechanisms in this study, the effect of HA nanoparticles on ovarian function should not be underestimated. Effects of nanoparticles on ovarian function should be extensively investigated in future. Stelzer et al recently reported that the amount of estrogen was significantly increased by treatment with 10 $\mathrm{nm}$ nanogold particles $\left(2.85 \times 10^{10}\right.$ particles $\left./ \mathrm{ml}\right)$ for $1,3,5$ $\mathrm{h}$, conversely attenuated by treatment for $24 \mathrm{~h}$, with rat ovarian granulosa cells [11]. There were differences in dosage, chemicals, particle size, and cell model between our study and Stelzer's report. And the cell models were different. Human luteinized granulosa cells have been exposed to pharmacological doses of exogenous gonadotropins, being in the process of undergoing differentiation to luteal cells with relatively limited capacity for cell 
proferation [16]. Because of the absence of granulosa cells from the unstimulated, human normal ovaries, these cells cultured in vitro now are useful cell model, to study cell cycle regulators, apoptosis, and related mechanisms involved in human ovary granulosa cell [17].

In conclusion, calcium phosphate nanoparticles interfered with cell cycle of cultured human ovarian granulosa cells thus increasing cell apoptosis. HA nanoparticles could enter into granulosa cells by many ways such as directly penetrating and endocytosis, and were located in thecal organelles, including lysosome and mitochondria. Although hormone production of the cultured granulosa cells was not significantly affected by $10 \mu \mathrm{M}$ and $100 \mu \mathrm{M}$ HA nanoparticles within $48 \mathrm{~h}$ treatment, this pilot study suggested that effects of nanoparticles on ovarian function should be extensively investigated.

\section{List of abbreviations}

HA: Hydroxyapatite; P450arom: P450aromatase; P450scc: cholesterol side chain cleavage enzyme; StAR: steroidogenic acute regulatory protein; TEM: transmission electron microscopy; UFPs: ultrafine particles.

\section{Competing interests}

The authors declare that they have no competing interests.

\section{Authors' contributions}

$\mathrm{XL}$ and DQ carried out cell culture, flow cytometry, RIA and molecular studies. $Y C$ and $J L$ designed the project. $Y C, X L$ and DQ write the manuscript. $L C, H L$ and ZC did nanoparticles and characterization, and helped to review the manuscript. XL and YC carried out TEM. LG participated in samples' work and worked as lab assistant. YL participated in design and performed the statistical analysis. $J \mathrm{~L}$ was director of the whole project. All authors read and approved the final manuscript.

\section{Acknowledgements}

The study was supported by the China 973 Program (No. 2007CB944005, 2007CB948103), and the Jiangsu Provincial Health Bureau Program (No. XK02200901-NG09, BM2008151). We also thank Dr Yifang Wang to help us to revise the manuscript.

\section{Author Details \\ 'Center of Clinical Reproductive Medicine, First Affiliated Hospital, Jiangsu Key Laboratory of Reproductive Medicine, Nanjing Medical University, Nanjing 210029, China, 2Department of Mechanical and Aerospace Engineering, University of Missouri, Columbia, MO 65211, USA, ${ }^{3}$ Department of Civil \& Environmental Engineering, University of Missouri, Columbia, MO 65211, USA, ${ }^{4}$ Jiangsu Family Planning Institute, Nanjing 210036, China and 5 Suzhou Municipal Hospital \& Suzhou Medical Center for Maternal and Child Health, Suzhou 215002, China}

Received: 11 January 2010 Accepted: 2 April 2010 Published: 2 April 2010

\section{References}

1. Oberdorster G, Oberdorster E, Oberdorster J: Nanotoxicology: an emerging discipline evolving from studies of ultrafine particles. Environ Health Perspect 2005, 113(7):823-839.

2. Brooking J, Davis SS, Illum L: Transport of nanoparticles across the rat nasal mucosa. J Drug Target 2001, 9(4):267-279.

3. Borm PJ, Kreyling W: Toxicological hazards of inhaled nanoparticlespotential implications for drug delivery. J Nanosci Nanotechnol 2004 4(5):521-531.
4. Oberdorster E: Manufactured nanomaterials (fullerenes, C60) induce oxidative stress in the brain of juvenile largemouth bass. Environ Health Perspect 2004, 112(10):1058-1062.

5. Oberdorster G, Maynard A, Donaldson K, Castranova V, Fitzpatrick J, Ausman K, Carter J, Karn B, Kreyling W, Lai D, Olin S, Monteiro-Riviere N, Warheit D, Yang H: Principles for characterizing the potential human health effects from exposure to nanomaterials: elements of a screening strategy. Part Fibre Toxicol 2005, 2:8.

6. Gupta M, Gupta AK: Hydrogel pullulan nanoparticles encapsulating pBUDLacZ plasmid as an efficient gene delivery carrier. J Control Release 2004, 99(1):157-166.

7. Colvin VL: The potential environmental impact of engineered nanomaterials. Nat Biotechno/ 2003, 21(10):1166-1170.

8. Foley S, Crowley C, Smaihi M, Bonfils C, Erlanger BF, Seta P, Larroque C: Cellular localisation of a water-soluble fullerene derivative. Biochem Biophys Res Commun 2002, 294(1):116-119.

9. Cai Y, Liu Y, Yan W, Hu Q, Tao J, Zhang M, Shi Z, Tang R: Role of hydroxyapatite nanoparticle size in bone cell proliferation. Journal of Materials Chemistry 2007, 17(36):3780-3787.

10. Wang Q, Huang W, Wang D, Darvell BW, Day DE, Rahaman MN: Preparation of hollow hydroxyapatite microspheres. J Mater Sci Mater Med 2006, 17(7):641-646.

11. Stelzer R, Hutz RJ: Gold nanoparticles enter rat ovarian granulosa cells and subcellular organelles, and alter in-vitro estrogen accumulation. J Reprod Dev 2009, 55(6):685-690.

12. Braydich-Stolle L, Hussain S, Schlager JJ, Hofmann MC: In vitro cytotoxicity of nanoparticles in mammalian germline stem cells. Toxicol Sci 2005, 88(2):412-419.

13. Zhao Y, Zhang Y, Ning F, Guo D, Xu Z: Synthesis and cellular biocompatibility of two kinds of HAP with different nanocrystal morphology. J Biomed Mater Res B App/ Biomater 2007, 83(1):121-126.

14. Fu Q, Rahaman M, Nai Zhou M, Wenhai Huang M, Deping Wang M, Liying Zhang M, Haifeng Li M: In vitro study on different cell response to spherical hydroxyapatite nanoparticles. Journal of Biomaterials Applications 2008, 23(1):37-50.

15. Fritz S, Kunz L, Dimitrijevic N, Grunert R, Heiss C, Mayerhofer A: Muscarinic receptors in human luteinized granulosa cells: activation blocks gap junctions and induces the transcription factor early growth response factor-1. J Clin Endocrinol Metab 2002, 87(3):1362-1367.

16. Fritz S, Fohr KJ, Boddien S, Berg U, Brucker C, Mayerhofer A: Functional and molecular characterization of a muscarinic receptor type and evidence for expression of choline-acetyltransferase and vesicular acetylcholine transporter in human granulosa-luteal cells. J Clin Endocrinol Metab 1999, 84(5):1744-1750.

17. Huang Q, Cheung AP, Zhang Y, Huang HF, Auersperg N, Leung PC: Effects of growth differentiation factor 9 on cell cycle regulators and ERK42/44 in human granulosa cell proliferation. Am J Physiol Endocrinol Metab 2009, 296(6):E1344-1353.

18. Zhou W, Liu J, Liao L, Han S, Liu J: Effect of bisphenol A on steroid hormone production in rat ovarian theca-interstitial and granulosa cells. Mol Cell Endocrinol 2008, 283(1-2):12-18.

19. Serpe L, Canaparo R, Daperno M, Sostegni R, Martinasso G, Muntoni E, Ippolito L, Vivenza N, Pera A, Eandi M, Gasco MR, Zara GP: Solid lipid nanoparticles as anti-inflammatory drug delivery system in a human inflammatory bowel disease whole-blood model. European Journal of Pharmaceutical Sciences

20. Wang X, Xu W, Kong X, Chen D, Hellermann G, Ahlert T, Giaimo J, Cormier S, Li X, Lockey R, Mohapatra S, Mohapatra SS: Modulation of lung inflammation by vessel dilator in a mouse model of allergic asthma. Respiratory Research 2009, 10(1):66.

21. Pezzatini S, Morbidelli L, Solito R, Paccagnini E, Boanini E, Bigi A, Ziche M: Nanostructured HA crystals up-regulate FGF-2 expression and activity in microvascular endothelium promoting angiogenesis. Bone 2007 41(4):523-534

22. Hoet PH, Bruske-Hohlfeld I, Salata OV: Nanoparticles - known and unknown health risks. J Nanobiotechnology 2004, 2(1):12.

23. Oberdorster G: Pulmonary effects of inhaled ultrafine particles. Int Arch Occup Environ Health 2001, 74(1):1-8

24. Jani P, Halbert GW, Langridge J, Florence AT: Nanoparticle uptake by the rat gastrointestinal mucosa: quantitation and particle size dependency. J Pharm Pharmacol 1990, 42(12):821-826. 
25. Kreilgaard M: Influence of microemulsions on cutaneous drug delivery. Adv Drug Deliv Rev 2002, 54(Suppl 1):S77-98.

26. Block ML, Wu X, Pei Z, Li G, Wang T, Qin L, Wilson B, Yang J, Hong JS, Veronesi B: Nanometer size diesel exhaust particles are selectively toxic to dopaminergic neurons: the role of microglia, phagocytosis, and NADPH oxidase. FASEB J 2004, 18(13):1618-1620.

27. Singh S, Shi T, Duffin R, Albrecht C, van Berlo D, Hohr D, Fubini B, Martra G, Fenoglio I, Borm PJ, Schins RP: Endocytosis, oxidative stress and IL-8 expression in human lung epithelial cells upon treatment with fine and ultrafine $\mathrm{TiO} 2$ : role of the specific surface area and of surface methylation of the particles. Toxicol Appl Pharmacol 2007, 222(2):141-151

28. Savic R, Luo L, Eisenberg A, Maysinger D: Micellar nanocontainers distribute to defined cytoplasmic organelles. Science 2003, 300(5619):615-618.

29. Simon-Deckers A, Gouget B, Mayne-L'hermite M, Herlin-Boime N, Reynaud C, Carriere M: In vitro investigation of oxide nanoparticle and carbon nanotube toxicity and intracellular accumulation in A549 human pneumocytes. Toxicology 2008, 253(1-3):137-146.

30. Conner SD, Schmid SL: Regulated portals of entry into the cell. Nature 2003, 422(6927):37-44.

31. Kastan MB, Bartek J: Cell-cycle checkpoints and cancer. Nature 2004 432(7015):316-323.

32. Gogvadze V, Orrenius S: Mitochondrial regulation of apoptotic cell death. Chem Biol Interact 2006, 163(1-2):4-14.

33. Green DR, Amarante-Mendes GP: The point of no return: mitochondria, caspases, and the commitment to cell death. Results Prob/ Cell Differ 1998, 24:45-61.

34. Li N, Sioutas C, Cho A, Schmitz D, Misra C, Sempf J, Wang M, Oberley T, Froines J, Nel A: Ultrafine particulate pollutants induce oxidative stress and mitochondrial damage. Environ Health Perspect 2003, 111(4):455-460.

35. Han J, Goldstein LA, Gastman BR, Rabinowich H: Interrelated roles for Mcl-1 and BIM in regulation of TRAIL-mediated mitochondrial apoptosis. J Biol Chem 2006, 281(15):10153-10163.

doi: $10.1186 / 1477-7827-8-32$

Cite this article as: Liu et al., The effect of calcium phosphate nanoparticles on hormone production and apoptosis in human granulosa cells Reproductive Biology and Endocrinology 2010, 8:32

Submit your next manuscript to BioMed Centra and take full advantage of:

- Convenient online submission

- Thorough peer review

- No space constraints or color figure charges

- Immediate publication on acceptance

- Inclusion in PubMed, CAS, Scopus and Google Scholar

- Research which is freely available for redistribution

Submit your manuscript at www.biomedcentral.com/submit
C Biomed Central 